\title{
Molecular Evolution of Prolactin Gene Single Nucleotide Polymorphisms in Nigerian Chicken Ecotypes and their Association with Light Ecotype Chickens' Egg Traits
}

\author{
Uberu $\mathrm{NP}^{1 *}$, Oleforuh-Okoleh $\mathrm{VU}^{2}$, Ndofor-Foleng $\mathrm{HM}^{1}$, Agaviezor $\mathrm{BO}^{3}$, Ohagenyi $\mathrm{JI}^{1}$, Udeh $\mathrm{FU}^{1}$, \\ Ani $\mathrm{AO}^{1}$, Nwosu $\mathrm{CC}^{1}$ and Akuru EA ${ }^{1,4}$ \\ ${ }^{1}$ Department of Animal Science, University of Nigeria, 410001, Nsukka, Enugu State, Nigeria \\ ${ }^{2}$ Department of Animal Science, Rivers State University of Science and Technology, Rivers State, Nigeria \\ ${ }^{3}$ Department of Animal Science, University of Port Harcourt, River State, Nigeria \\ ${ }^{4}$ Department of Livestock and Pasture Science, University of Fort Hare, Alice 5700, South Africa \\ *Corresponding author: nkiru.uberu@unn.edu.ng; nkiru2favored@gmail.com
}

\begin{abstract}
\begin{tabular}{llll}
\hline Article History: 21-337 & Received: 16-Jun-21 & Revised: 12-Jul-21 & Accepted: 16-Jul-21
\end{tabular}
\section{ABSTRACT}

The prolactin (PRL) gene influences the commencement of incubation and brooding behavior and egg production, particularly in native birds. In this study, the first experiment was performed to screen the PRL candidate gene for single nucleotide polymorphisms (SNPs) in four different morphological types of Nigerian chicken, and to evaluate their molecular evolutionary changes. To achieve this first objective, a 130-base pair (bp) fragment of PRL was sequenced in 40 different Nigerian chicken types namely, 13 Heavy Ecotype (HE) cocks and hens, 13 Light ecotype (LE) cocks and hens, 7 Frizzled Feathered (FF) cocks and 7 Naked Neck (NN) cocks. In the second experiment which aimed to associate the SNPs of the LE PRL with egg traits, 13 LE cocks and hens from the indigenous flock were screened. Three SNPs were identified in the Nigerian chicken ecotypes ( $\mathrm{A}=$ Adenine, $\mathrm{G}=\mathrm{Guanine}, \mathrm{C}=\mathrm{Cy}$ tosine, and $\mathrm{T}=\mathrm{Thymine}$ ), namely $\mathrm{G}>\mathrm{T}, \mathrm{T}>\mathrm{C}$ and $\mathrm{A}>\mathrm{C}$ having allelic frequencies of 7 in NN, 10 in $\mathrm{HE}$ and 4 in both FF and LE chickens. Comparison of the chicken PRL (cPRL) sequence gave 98\% homology with White Leghorn (Accession No. AB013783.3). The Tajima "D" test of neutral molecular evolutionary rate was 2.79 , suggesting balancing selection in the cPRL. In associating the SNPs with egg traits of LE, three SNPs were identified in the LE chickens namely G $>\mathrm{T}, \mathrm{T}>\mathrm{C}$ and $\mathrm{A}$ $>\mathrm{C}$ having allelic frequencies of 4, 3 and 4, respectively. The cPRL genomic sequence consisted of $154 \mathrm{bp}$ long. The T $>\mathrm{C}$ polymorphism showed significant $(\mathrm{P}<0.05)$ negative association with egg number and egg size. The findings in the second experiment showed that the homozygous TT genotypes showed better egg weight and egg number performances than the TC individuals.
\end{abstract}

Key words: Nigerian chicken, prolactin, SNP, evolutionary, mutation, ecotypes.

\section{INTRODUCTION}

Poultry production, especially of domestic chickens, like the Nigerian Indigenous chicken (NIC) occupies a central position in the nation's attainment of animal protein sufficiency. This is because the NIC is mainly involved in improving the livelihood of rural people, thereby contributing substantially to the gross domestic product of the nation. The NIC are resilient birds that can survive any prevailing local environmental conditions (Ajayi 2010; Betridge et al. 2018; Shaw et al. 2019). The origin of each strain or ecotype of the NIC is the product of mutation, genetic drift, adaptation and evolution. The different selection pressures imposed on these chickens include the diet, variation in climate, endemic parasites and diseases (Agbaje and Alabi 2018).

Genetic markers, unlike morphological markers (which are mostly visible mutations), can detect and analyze genetic differences between individuals, populations, and species at the level of organism's DNA. However, the usefulness of genetic markers is directly related to the presence of gene polymorphisms. Over the years, there has been considerable interest in the genetic control of egg production and egg size in poultry, especially in chickens. The prolactin (PRL) gene consist of five exons and four introns and is one of the gene markers

Cite This Article as: Uberu NP, Oleforuh-Okoleh VU, Ndofor-Foleng HM, Agaviezor BO, Ohagenyi JI, Udeh FU, Ani AO, Nwosu CC and Akuru EA, 2022. Molecular evolution of prolactin gene single nucleotide polymorphisms in Nigerian Chicken Ecotypes, and their association with light ecotype chickens' egg traits. International Journal of Veterinary Science 11(1): 91-97. https://doi.org/10.47278/journal.ijvs/2021.079 
that affects poultry birds' egg production traits (Wang et al. 2011; Sonmez and Ozdemir 2017; Yournalis et al. 2019). Constant research on the PRL is therefore, critical to understanding the genetic basis of optimal egg production in chicken (Osman et al. 2017). There are previous reports on the complete sequence of the chicken PRL (cPRL), and its polymorphism (Mihailov et al. 2014; Liang et al. 2019). There have also been studies done to determine the existing correlation amongst gene polymorphism and egg production indices in poultry species of various kinds (Ohkubo et al. 2000; Cui et al. 2006; Chen et al. 2012; Rashidi et al. 2012; Osman et al. 2017).

It has been shown that single-nucleotide polymorphisms (SNPs) are a simple class of gene polymorphism, that occur due to a single base substitution, for instance, cytosine being substituted for thymine, amongst others. SNPs occur more frequently in the introns, exons, promoters and intergenic regions of animal genomes (Collins et al. 2016; Lim et al. 2019). More than 90\% of differences recorded amongst individuals have been attributed to SNPs. To this end, SNPs are considered as veritable tools for conducting studies on any given population, and for mapping and selecting genomes (Spötter et al. 2016; Visscher et al. 2017; Kim et al. 2018; Lo et al. 2018). The aims of the current study were to evaluate the rate of molecular evolutionary changes in the chicken prolactin (cPRL) gene, in four Nigerian chicken ecotypes and to examine the association of the SNPs in the cPRL with egg production traits in the Nigerian Light Ecotype chickens.

\section{MATERIALS AND METHODS}

\section{Study Locations and Climatic Conditions}

The experiments were carried out in three locations in Nigeria namely: the Indigenous Poultry section in the Poultry Unit of the Department of Animal Science, University of Nigeria, Nsukka (UNN); the Molecular Laboratory of the Department of Animal Science, University of Port Harcourt; and the International Institute for Tropical Agriculture (IITA), Ibadan. The climatic conditions of the three different study areas (Nsukka, Port Harcourt and Ibadan) had earlier been reported (Agbagha et al. 2000; Eginola and Amobichukwu 2013; Edokpa and Nwagbara 2017).

\section{Description of Experimental Population and their Management (experiments 1 and 2) \\ Experiment 1: A total of 40 chickens of both sexes were used in the evaluation. These were 13 Heavy Ecotype (HE) cocks and hens, 13 Light ecotype (LE) cocks and hens, the 7 Frizzled Feathered (FF) cocks and 7 Naked Neck (NN) cocks. The different Ecotypes were sourced from stocks of the Indigenous Poultry Unit in the Department of Animal Science, UNN. The birds were housed in individual battery cages and fed a daily ration of 125 grams of a commercial layers' mash diet (Vital ${ }^{\circledR}$ brand). Water was supplied to the birds ad libitum.}

In Experiment 2: A total of 13 Light Ecotype cocks and hens were used. The ecotypes were obtained from the same source as those in experiment 1 , and genotyped. The housing, feeding and management of the birds were the same as already described. According to Momoh et al. (2007) Light Ecotypes are chicken types that weigh 0.68$1.5 \mathrm{~kg}$, and which emanate from the swamp, rainforest and derived savanna agro-ecological zones.

\section{Animal Blood Evaluation and DNA Isolation}

The methods for blood evaluation and DNA isolation were the same for both experiments. The study's ethical protocols were as permitted by the Scientific Research and Bio-Ethics Committee of the University of Nigeria, Nsukka. Approximately 2-3mL of blood was collected per live bird from the wing veins and placed in EDTA-treated bottles. The blood samples were stored at freezer temperature of $-4^{\circ} \mathrm{C}$ for a week, prior to the DNA extraction. Whole blood tissues were thawed at room temperatures of $24^{\circ} \mathrm{C}$. Genomic DNA samples were isolated using a commercially available $\mathrm{ZymoBead}^{\mathrm{TM}}$ Genomic DNA kit (ZYMO Research Corp., Irvine, CA, USA) protocol. The yield and quality of the extracted DNA were evaluated using a NanodropND- 100 UV/ Spectrophotometer (NanoDrop Technologies, Inc. Wilmington, DE, USA). Final concentrations between 2 and $10 \mathrm{ng} / \mu \mathrm{L}$ were detected (Fig. 1). All procedures adopted in the blood collection process were based on the approved animal welfare ethical standards.

\section{PCR-RFLP Amplification and Sequencing of PRL Gene (experiments 1 and 2)}

A working concentration of $10 \mathrm{ng} / \mu \mathrm{L}$, was obtained by diluting the stock DNA sample, and was used for the PCR analysis. Forward and reverse primers (F: 5'TTTAATATTGGTGGGTGAAGAGACA-3' and R: 5' ATGCCACTGATCCTCGAAAACTC-3') designed based on the SNPs of the prolactin candidate gene, were used to amplify a 154 base-pair product of the chicken PRL gene. The amplifications of the PCR were done in a total of $25 \mu \mathrm{L}$ reaction volume. The reaction volume contained approximately 20ng DNA, with $1.0 \mu \mathrm{L}$ each of $25 \mathrm{Mm}$ of $\mathrm{MgCl}_{2}, 5 \mathrm{pmol}$ of each primer, DMSO and $2.0 \mu \mathrm{L}$ of $2.5 \mathrm{Mm}$ DNTPs with one unit of dream Taq Quick Load 2X Master Mix with standard buffer (Zymobead® Research Inc.) Thermo-cycling conditions were in two steps, and were initially denatured for $5 \mathrm{~min}$ at $94^{\circ} \mathrm{C}$. In the first step, nine amplification cycles of $94^{\circ} \mathrm{C}$ for $5 \mathrm{~min}$ was done to activate DNA polymerase enzyme, then $94^{\circ} \mathrm{C}$ for $15 \mathrm{sec}$, and then annealed for $20 \mathrm{sec}$ at $65^{\circ} \mathrm{C}$, then for $30 \mathrm{sec}$ at $72^{\circ} \mathrm{C}$. In the second step, 35 cycles of denaturation were done for $15 \mathrm{sec}$ at $94^{\circ} \mathrm{C}$, followed by a toughening for $20 \mathrm{sec}$ at $55^{\circ} \mathrm{C}$. This was initially extended for $30 \mathrm{sec}$ at $72^{\circ} \mathrm{C}$, and finally extended for $7 \mathrm{~min}$ at $72^{\circ} \mathrm{C}$. Thereafter, the products were preserved at a freezer temperature of $10^{\circ} \mathrm{C}$.

\section{Electrophoresis Procedure of PCR Amplification Products (experiments 1 and 2)}

The method of electrophoresis was used to analyze the PCR products for $15 \mathrm{~min}$, using a $2 \%$ agarose gel at $110 \mathrm{~V}$, $400 \mathrm{~mA}$. After that, the ultraviolet (UV) light was used to observe the banding patterns. An overnight digestion of the products was then done, in an incubator that was set at $37^{\circ}$ $\mathrm{C}$ and contained a restriction enzyme $(10 \mu \mathrm{L})$ (Taq 1). The resultant products of digestion were electrophoresed for $30 \mathrm{~min}$ at 80 Volt on $3 \%$ agarose gel. A visualization of the banding pattern under UV light was then carried out, in 
order to determine the PCR-RFLP (restricted fragment length polymorphism) fragment sizes.

\section{PCR Purification and DNA Sequencing (experiments 1 and 2)}

The Zymobead purification system (Zymobead ${ }^{\circledR}$ Research Inc.) was used to purify the PCR products. Thereafter, the methods described by Sambrook and Russell (2001) were used to clone the products into the Promega pGEM-T easy vector (Cwbio, Beijing, China). A commercial sequencing of the resultant fragments was done at the IITA, Ibadan, Nigeria, using the Applied Biosystems Automated 3730 DNA Analyzer, and the ABI Prism Big-Dye $\AA$ Terminator version 3.1 Cycle Sequencing kit (Applied Biosystems, Foster City, CA, USA).

SNP Identification and Genotyping (Experiments 1 and 2)

The SNPs were identified with the aid of DnaSP version 5. Genotypes were obtained from analysing and comparing the chromatograms of the obtained sequences. In order to confirm the expected gene sequences of the cPRL, the sequences were analyzed using the basic local alignment search tool (Altschul et al. 1990).

\section{Statistical Analyses}

Experiment 1: The indices of the variation and structure of the sequence were evaluated using DNAsp version 5.10.01; and the results obtained were validated using Molecular Evolutionary Genetic Analysis (MEGA) version 6.0. To identify the nucleotide substitutions, the MEGA software was used to align the resulting DNA sequences (Tamura et al. 2013). This software and the DNAsp version 5 were also used to determine the SNP and other sequence variation parameters. The GENEPOP Software package version 4 was then used to estimate the allele and genotype frequencies (Raymond 2008), whereas, PAST and Tools for Population Genetic Analyses (TFPGA) version 1.3, was used to analyse the other genetic data (Miller 1997). The MEGA software was also used to analyze the evolutionary data, while the Tajima $D$ test (1989) was used to test the hypothesis of neutral polymorphisms. Usually, a Chi- square $\left(\chi^{2}\right)$ test is used to test the statistical difference in evolutionary rates between the two sequences, $\mathrm{A}$ and $\mathrm{B}$.

Experiment 2: The effect of the SNP on egg weight and egg number was analysed using SPSS version 16. Means were separated using Duncan's New Multiple Range Test (Duncan 1955), whereas the one-way ANOVA was done to determine the SNP effect on egg number and egg size.

\section{RESULTS}

\section{Experiment 2}

\section{Molecular Evolutionary Rates Test between Chicken Ecotypes}

The equality of evolutionary rate in Tajima's relative test (Tajima 1993) between the sequences A (FFM5) and B ( $L E F 1)$, with sequence $\mathrm{C}(N N M 1)$ used as an out-group, was examined (Tables 1 and 2). The calculation and statistical test of the Tajima's D test (Tajima 1989) was based on the molecular clock hypothesis of steady accumulated rate of changes in the DNA.

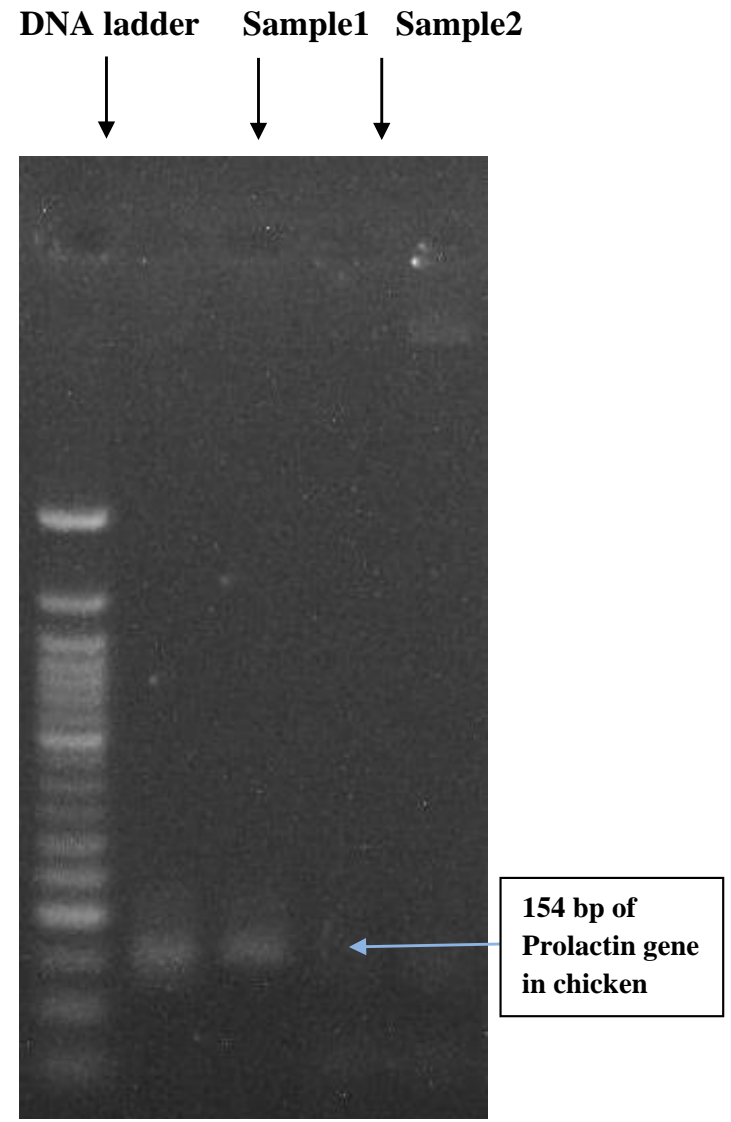

Fig. 1: Ultra-violet photograph of the gel image of chicken PRL gene quality assessment. (Lane 1 is $1 \mathrm{~kb}$ DNA ladder). Sample 1 and 2 are chicken samples.

Table 1: Tajima's Test for Three Sequences

\begin{tabular}{lc}
\hline Configuration & Count \\
\hline Identical sites in all three sequences & 47 \\
Divergent sites in all three sequences & 6 \\
Unique differences in Sequence A & 51 \\
Unique differences in Sequence B & 9 \\
Unique differences in Sequence C & 3
\end{tabular}

Note: The analysis involved 3 nucleotide sequences. Codon positions included were $1 \mathrm{st}+2 \mathrm{nd}+3 \mathrm{rd}+$ Noncoding. All positions containing gaps and missing data were eliminated. There were a total of 116 positions in the final dataset.

Table 2: Tajima's Neutrality Test [1]

\begin{tabular}{cccccc}
$M$ & $S$ & $p_{\mathrm{s}}$ & $\Theta$ & $\Pi$ & $D$ \\
\hline 20 & 89 & 0.847619 & 0.238918 & 0.401855 & 2.794497
\end{tabular}

Abbreviations Used and their explanations: $m=$ number of sequences: $n=$ total number of sites: $S=$ Number of segregating sites, i.e. the number of polymorphic sites: $p_{\mathrm{s}}=S / n, \Theta=p_{\mathrm{s}} / \mathrm{a}_{1}$ : $\pi=$ nucleotide diversity, and $D$ is the Tajima test statistic: NOTE: The analysis involved 20 nucleotide sequences. Codon positions included were $1 \mathrm{st}+2 \mathrm{nd}+3 \mathrm{rd}+$ Noncoding. All positions containing gaps and missing data were eliminated. There was a total of 105 positions in the final dataset.

Table 3: DNA polymorphism and frequencies of cPRL gene of Light Ecotype chicken

\begin{tabular}{lcc}
\hline SNPs & Frequencies & Percentages \\
\hline G-G & 0 & 0 \\
G-T & 4 & 100 \\
T-T & 1 & 25 \\
T-C & 3 & 75 \\
A-A & 0 & 0 \\
A-C & 4 & 100 \\
\hline
\end{tabular}




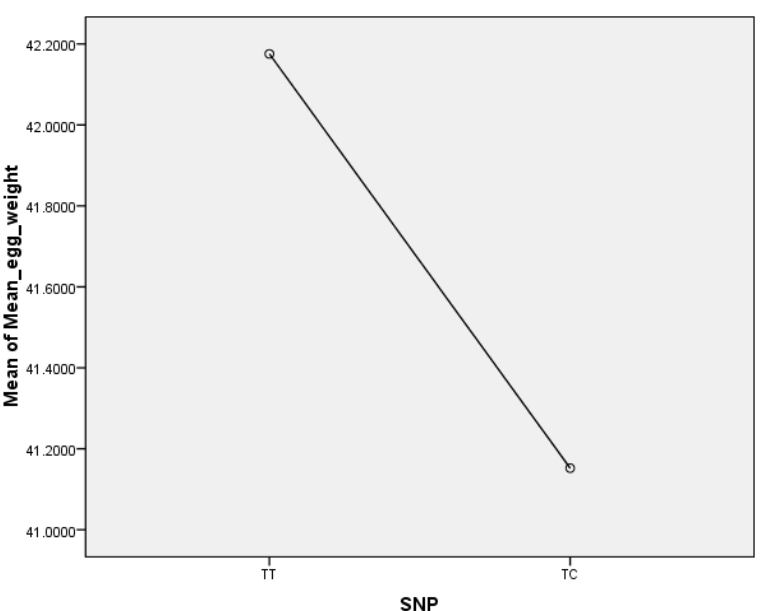

Fig. 2: Mean plots between SNP groups for egg weight.

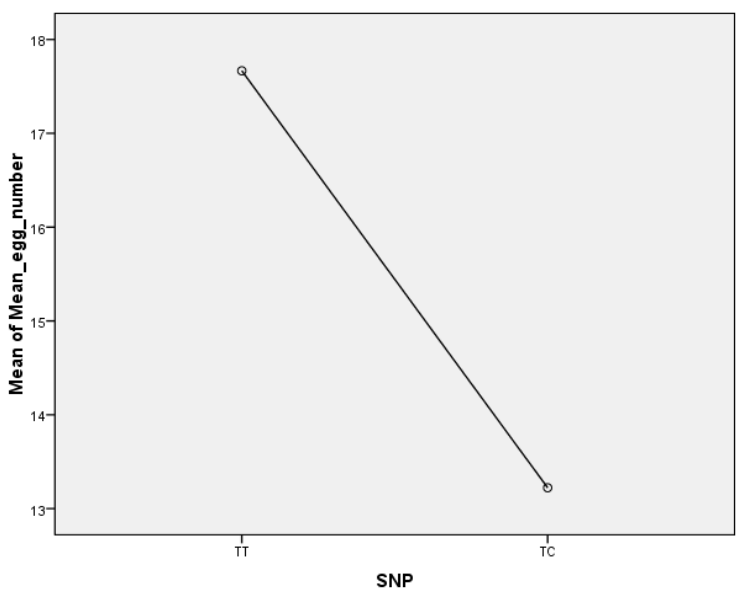

Fig. 3: Mean plots between SNP groups for egg number.

\section{Experiment 2}

DNA Polymorphisms and Frequencies of SNPs in Prolactin Gene of Light Chicken Ecotype

The PCR primers yielded a 130 base pair fragment, of which 20 are conserved regions, and 106 are parsimonyinformative variables. Analysis of the cPRL gene sequences showed a total of three unique single nucleotide polymorphic loci in the Nigerian Light Ecotype chickens studied. The three SNPs namely, G-T, T-C and A-C of the prolactin gene identified had frequencies of 4,3 and 4 (Table 3).

\section{Association of PRL Polymorphism with Mean Egg Number and Egg Size in Nigerian Light Ecotype}

The means \pm standard deviations for the main effect of SNP on both the egg numbers per hen per month, and the egg size are shown in Tables 4. Only the T-C/ T-T single nucleotide site was found to be polymorphic for the Light Ecotype chicken.

\section{Mean Plots Between SNPs for Egg Weight and Egg Number}

The mean plots between SNPs for egg weight and number are shown in Figures 2 and 3. The plots which were used to detect slight changes in location between the two genotypic groups of (i.e., the T-C and T-T) single nucleotide polymorphism, showed shift of location after the TT genotypes.

\section{DISCUSSION}

\section{Experiment 1}

Battistuzzi et al. (2011) opined that molecular clock tests are used to ascertain whether the significant variation in molecular evolution rates, occur among taxonomic groups, or phylogenetic lineages. The $\chi 2$ test statistic value obtained in the study was 29.40 ( $\mathrm{P}<0.000001 ; 1 \mathrm{df})$. Usually P-values of less than 0.05 are often used to reject the null hypothesis of neutral or equal evolutionary rates between sequences or lineages. In other words, the changes in the prolactin gene sequence did not occur at the same rate in the four ecotypes.

Population dynamics usually determine the sign of Tajima's $D$. A negative Tajima's $D$ (and/or Fu and Li's $D$ ) is tantamount to positive selection, which is linked to an excess of rare alleles. Thus, positive selection is a product of an increased population size (Omori and Wu 2017). However, balancing selection is shown by a positive Tajima's $D$ (and/or Fu and Li's $D$ ) and is associated with an excess of high-frequency variation (Panhuis and Swanson 2006). A positive Tajima's $D$ is said to result from a decreased population size. Hence, the significantly positive Tajima's $D$ value of 2.7945 obtained in this study (Table 2) suggests that the chicken prolactin gene may be undergoing balancing selection. Balancing selection refers to several selective mechanisms particularly, heterozygote advantage and frequency-dependent selection (Charlesworth 2006). Balancing selection has been reported to maintain mutations at intermediate frequencies (Panhuis and Swanson 2006). Genetic polymorphisms (or multiple alleles of a gene) are sustained in the population by balancing selection, at higher frequencies than is expected from only genetic drift, which is evidenced by the number of alleles in a population which are maintained above mutation rate frequencies (Takahata 1990; Vekemans and Slakkin 1994).

Table 4: Means of both egg weight and egg number of the LE chicken for the T-C SNPs of PRL gene

\begin{tabular}{|c|c|c|c|c|c|c|c|c|c|}
\hline \multirow[t]{2}{*}{ Egg Production Traits } & \multirow[t]{2}{*}{1} & \multirow[t]{2}{*}{$\mathrm{N}$} & \multirow[t]{2}{*}{ Mean } & \multirow[t]{2}{*}{$\mathrm{SD}$} & \multirow[t]{2}{*}{ SE } & \multicolumn{3}{|c|}{ 95\% Confidence Interval for Mean Minimum } & \multirow[t]{2}{*}{ Maximum } \\
\hline & & & & & & Lower Bound & Upper Bound & & \\
\hline \multirow[t]{3}{*}{ Mean_Egg weight (g) } & TT & 3 & $42.17546 \mathrm{E} 1$ & 7.1870882 & 4.1494673Е0 & 24.321746 & 60.029180 & 37.4875 & 50.4500 \\
\hline & $\mathrm{TC}$ & 9 & $41.15204 \mathrm{E} 1$ & 4.8907319 & $1.6302440 \mathrm{E} 0$ & 37.392692 & 44.911391 & 34.7833 & 48.1800 \\
\hline & Total & 12 & 41.40790E1 & 5.1963201 & 1.5000484E0 & 38.106313 & 44.709481 & 34.7833 & 50.4500 \\
\hline \multirow[t]{3}{*}{ Mean_Egg number } & TT & 3 & 17.67 & 9.713 & 5.608 & -6.46 & 41.79 & 7 & 26 \\
\hline & $\mathrm{TC}$ & 9 & 13.22 & 7.396 & 2.465 & 7.54 & 18.91 & 4 & 25 \\
\hline & Total & 12 & 14.33 & 7.808 & 2.254 & 9.37 & 19.29 & 4 & 26 \\
\hline
\end{tabular}

SD: Standard deviation, SE: Standard error. T: Thymine, C: Cytosine: Means Plots. 
The Tajima's D test is one of the several recommended methods for assessing the natural selection of mutations at specific sites. This test is an important statistical test for evaluating the neutrality of evolution at the sequence level, in that; it is a measure of the difference between two estimates of genetic diversity. In this study, the estimated nucleotide diversity $(\pi)$ between the four chicken ecotypes, varied at the rate of $0.40 \times 10^{-6}$. When evolution is neutral, the estimates are noted to be equal, and denoted by a zero Tajima's D (i.e., Tajima's $\mathrm{D}=0$ ). In view of this, a nonzero Tajima's D is indicative of a natural selection, in which case, there is a violation of at least one of the conditions for neutral evolution (Battistuzzi et al. 2011).

\section{Experiment 2}

The demand for SNP detection technologies is relatively high. This is due to its use in the scan for new/ unknown polymorphism, as well as screening/ genotyping individuals, to determine the alleles of known polymorphisms in target sequences (Kwok and Chen 2003; Reshma and Das 2021). In addition, Kansaku et al. (2008) reported that the PRL gene in avian is not much prone to variation (i.e., highly conserved). In the results obtained (Table 3), it was evident that the LE individuals are all the heterozygous G-T genotype, suggesting the total absence of polymorphism or mutation at this nucleotide site in this ecotype. Moreover, one can suppose that the G-T genotype has become fixed in the LE ecotype population, and that could be as a result of the mechanisms of balancing selection. This outcome is of biological relevance, as it could be attributed to the establishment of selectively mutant individual with time, and consequently, denoting an heterozygotes fitness advantage, over the probable less fit homozygotes G-G genotypes (Marks and Ptak 2000; Cordero and Janzen 2013). This may probably be because an overriding factor in allele fixation in any natural population is the fitness of the genotype. The authors also observed that there is a much faster progression of high heterozygote fitness than high homozygote fitness. Watahiki et al. (1989) and Cui et al. (2006) also made similar observations.

As a matter of fact, findings from studies which had been done to detect polymorphisms in the chicken PRL gene have shown that the PRL is a crucial gene that affects egg production.

Several SNPs have been reported in the cPRL gene. For instance, Cui et al. (2006) reported six SNPs and 24base pair insertions-deletions (indels) from direct sequencing. These SNPs were identified as C-2402T, C2161G, T-2101G, C-2062G, T-2054A and G-2040A. Also, association studies have shown that the indels were correlated with traits in chickens, such as egg production and broodiness (Wang et al. 2011). Liu et al. (2007) screened three mutations, C-1607T, C-5749T and T5821C; and reported that different haplotypes and egg production traits were correlated. However, to the best of our knowledge, this is the first work on SNP approach to the study of the Nigerian indigenous chicken prolactin gene and its association with Light Ecotype chicken's egg traits. Notwithstanding, association studies have been done on morphometric and growth traits in some breeds of the Nigerian chicken, including the indigenous birds (Okafor et al. 2019; Bello et al. 2020). In a recent study of Okafor et al. (2019) the chicken growth hormone SNP was associated with morphometric and growth traits in the NIC in addition to Funaab Alpha and ShikaBrown. The SNP results revealed a two bp substitution mutation on locus 6 chromosome for the NIC. The NIC had more haplotypes (6), suggesting increased allelic variations than the other breeds. In the present study however, only the T-C single base genotype was polymorphic in the LE chickens. Hence, these polymorphisms of prolactin as candidate gene could serve as useful physiological markers, to increase egg production in the Nigerian chicken population. In the same vein, Bello et al. (2020) reported that the Pituitary Specific transcription factor 1 (PIT-1) gene evaluated in their study was polymorphic with genotypes $\mathrm{AA}$ and $\mathrm{AB}$ in the Fulani and Yoruba ecotypes of the NIC studied. According to these authors, the PIT-1 genes were statistically associated with the chickens' body weight. Similarly, a recent work was done in Western Kenya to describe the phenotypic traits of emerging poultry birds and determine the polymorphisms in PRL and Vasoactive Intestinal Peptide receptor 1 (VIPR1) candidate genes for egg traits in these birds (Macharia 2018). The results of the study showed that the prolactin and VIPR1 sequences of the pigeon and quail birds formed four and eight haplotypes, respectively, whereas those of the other poultry birds were monomorphic (Macharia 2018).

In this study, both egg number and egg weight were affected negatively, but did not differ statistically $(\mathrm{P} \geq 0.05)$ between the TT and TC SNP genotypes (Table 4). The result of this study compares favorably with the findings of (Osman et al. 2017) which showed significant differences $(\mathrm{P} \leq 0.012)$ between the three chicken strains (Lohmann, Cobb 500, and Avian 48) with zero SNPs found and the Hubbard F15 strain, which contain three SNPs in PRL gene. Similarly, Okafor et al. (2019) reported that the association of SNP genotypes showed no statistical association effects on all parameters evaluated, except for the $\mathrm{CC}$ genotype that was significantly associated with $\mathrm{CA}$ genotypes for shank length in the NIC.

The mean plots (Figures 2 and 3 ) for egg weight and egg number respectively were used to detect slight changes in location between the two genotypic groups of the T-C and T-T single nucleotide polymorphism. Mean plots for both egg weight and egg number per month showed shift of location after the TT genotypes. All things being equal however, in the present study, the homozygous TT genotypes/ individuals showed better egg weight and egg number performances than the TC genotypes/ individuals.

\section{Conclusion}

Being the first work done on SNP approach to the study of the Nigerian cPRL, we were able to establish the existence of heterozygous fitness in the light ecotype chickens, and high correlations with egg number and size in the homozygotes. It is suggested that more confirmatory studies be done to ratify these findings.

\section{Author's Contribution}

UNP: Design and methodology, experimentation, data collection, statistical analysis, Writing: Original draft. OOVU: Assisted in data collection. NFHM: Assisted in data collection. ABO: Assisted in laboratory analysis. OJI: Assisted in data collection. UFU: Assisted in data 
collection. AAO: Supervisory assistant, Writing: Review and editing. NCC: Supervision, Writing: Review and editing. AEA: Writing: Review and editing.

\section{Acknowledgement}

Authors are grateful to the Department of Animal Science, University of Nigeria Nsukka, the Molecular Laboratory of the Department of Animal Science, University of Port Harcourt and the International Institute of Tropical Agriculture, Ibadan for providing the facilities used for this study.

\section{REFERENCES}

Agbagha FM, Ezema FU and Omeke BCO, 2000. Studies of management effects on fertility of purebred and crossbred exotic gilts in two breeding farms at Nsukka. Nigerian Journal of Animal Production 28: 20.

Agbaje HA and Alabi OO 2018. Application of gis for biodiversity conservation of indigenous chickens. IOSR Journal of Agriculture and Veterinary Science 11: 18-38.

Ajayi FO, 2010. Nigerian indigenous chicken: A valuable genetic resource for meat and egg production. Asian Journal of Poultry Science 4: 164-172. https://doi.org/10.3923/ajpsaj. 2010.164.172

Altschul AF, Gish W, Miller W, Myers EW and Lipman DJ, 1990. Basic local alignment search tool. Journal of Molecular Biology 215: 403-410. https://doi.org/10.1016/S002836(05)803602

Battistuzzi FU, Filipski A and Kumar S, 2011. Molecular clock: Testing. eLS. Wiley and Sons Ltd. https://doi.org/ 10.1002/9780470015902.90001803.pub2

Bello SF, Akinyemi MO, Fata RB, Kwuda MK, Ahmed RO, Oyelami, FO, Akinyemi FF and Olasege BS, 2020. Detection of polymorphism of pituitary specific transcription factor 1 gene and its association with body weight of Fulani and Yoruba ecotype chickens. Open Journal of Animal Sciences 10: 278-286. $\quad$ https://doi.org/10.4236/ ojas.2020.102016

Betridge JM, Psifidi A, Terfa ZG, Desta TT, Lozano-jaramillo MT, Kaiser P, Wigley P, Hanotte O and Christley RM, 2018. The role of local adaptation in sustainable production of village chickens. Nature Sustainability 1: 574-582. https://doi.org/10.1030/s41893-018-0150-9

Charlesworth D, 2006. Balancing selection and its effects on sequence in nearby genome region. PLoS Genetics 2: e64.

Chen J, Liu H, Cai Y and Liu H, 2012. Mutations in the exon 10 of prolactin receptor gene change the egg production performance in Wanjiang white goose. Molecular Biology Reports 39: 475-483. https://doi.org/10.1007/s11033-0110761-y

Collins SA, Lockett GA and Holloway JW, 2016. The genetics of allergic diseases and asthma. In: Pediatric allergy: principles and practice. Leung DYM, Sampson H and Szefler S (ed), Elsevier Ltd, pp: 18-30. https://doi.org/10.1016/B975-03239875-9-000003-3

Cordero GA and Janzen F, 2013. Does life history affect molecular evolutionary rates? Nature Education Knowledge 4: $1-6$.

Cui JX, Du HL, Liang Y, Deng XM, Li N and Zhang XQ, 2006. Association of polymorphisms in the promoter region of chicken prolactin with egg production. Poultry Science 85: 26-31. https://doi.org/10.1093/ps/85.1.26

Duncan DB, 1955. Multiple range test and multiple F- tests. Biometrics 11: 1-42.

Edokpa DO and Nwagbara MO, 2017. Atmospheric stability pattern over Port Harcourt, Nigeria. Journal of Atmospheric Pollution 5: 9-17. https://doi.org/10.12691/jap-5-1-2
Eginola CN and Amobichukwu AC, 2013. Climate variation assessment based on rainfall and temperature in Ibadan, South-Western, Nigeria. Journal of Environmental and Earth Science 3: 32-45.

Kansaku N, Hiyama G, Sasanami T and Zadworny D, 2008. Prolactin and growth hormone in birds: protein structure, gene structure and genetic variation. The Journal of Poultry Science 45: 1-6. https://doi.org/10.2141/ipsa.45.1

Kim JM, Santure AW, Barton HJ, Quinn JL, Cole EF, Consortium GTH, Visser ME, Sheldon BC, Groenen MAM, Van Oers K and Slate J, 2018. A high-density SNP chip for genotyping great tit (Parus major) populations and its application to studying the genetic architecture of exploration behaviour. Molecular Ecology Resources 18: 877- 891. https://doi.org/ $\underline{10.1111 / 1755-0998.12778}$

Kwok P and Chen X, 2003. Detection of Single Nucleotide Polymorphisms. Current Issues in Molecular Biology 5: 4360.

Liang Ke, Wang X, Tian X, Geng R, Li W, Jing Z, Han R, Tian Y, Liu X, Kang X and Li Z, 2019. Molecular characterization and an 80-bp indel polymorphism within the prolactin receptor (PRLR) gene and its association with chicken growth and carcass traits. 3 Biotech 9: 296. https://doi.org/10.1007/S/3205-019-1827-0

Lim B, Kim S and Do K, 2019. Investigation of single nucleotide polymorphism in procine candidate genes for blood component traits in pigs. South African Journal of Animal Science. 49: 91-98. http://dx.doi.org/10.4314/sajas.v49i1.11

Liu HG, Wang XH, Liu YF, Zhao XB, Li N and Wu CX, 2007. Analysis of the relationship between codon frequency of prolactin gene and laying performance in five chicken breeds. Progress in Biochemistry and Biophysics 34: 11011106.

Lo E, Bonizzoni M, Hemming-Schroeder E, Ford A, Janies DA, James AA, Afrane Y, Etemes H, Zhou, G, Githeko A and Yan G, 2018. Selection and utility of single nucleotide polymorphism markers to reveal fine-scale population structure in human malaria parasite plasmodium falciparum. Frontiers in Ecology and Evolution. 6: 1-18. https://doi.org/ $10.3389 /$ fevo.2018.00145

Macharia WJJ, 2018. Phenotypic characterization and functional polymorphisms at prolactin and VIPR1 genes in emerging poultry species from Western Kenya. (MSc thesis). Jomo Kenyatta University of Agriculture and Technology, Kenya. Available at: http://ir.jkuat.ac.ke/bitstream/handle/ 123456789/4514/Macharia\%2C\%20Joyce\%20Jane\%20Wa ngui $\% 20 \mathrm{MSc} \% 20$ Biotech. $\% 2 \mathrm{C} \% 2018$.pdf? sequence $=1 \&$ is Allowed=y

Marks RW and Ptak SE, 2000. The Maintenance of Single-locus Polymorphism. V. Sex-dependent Viabilities. Selection 1: 217-228. https://doi.org/10.1556/select.1.2000.1-3.21

Mihailov N, Usatov A, Getmantseva L and Bakoev S, 2014. Associations between PRLR/AluI gene polymorphism with reproductive, growth, and meat traits in pigs. Cytology and Genetics 48: 323-326. https://doi.org/10.3103/S0095452 714050053

Miller MP, 1997. Tools for Population Genetic Analyses (TFPGA). Version 1.3. Department of Biological Sciences, Northern Arizona University Flagstaff, AZ, USA https://www.ccg.unam.mx/ vinuesa/tlem09/docs/TFPGAD OC.PDF

Momoh OM, Ehiobu NG and Nwosu CC, 2007. Egg production of two Nigerian local chicken ecotypes under improved management. Proc. 32nd Annual conference of Nigerian Society for Animal Production, March 18-22, University of Calabar, Nigeria pp: 278-281.

Ohkubo T, Tanaka M and Nakashima K, 2000. Molecular cloning of the chicken prolactin gene and activation by Pit-1 and cAMP-induced factor in GH3 cells. General and 
Comparative Endocrinology 119: 208-216. https://doi.org/ $\underline{10.1006 / \text { gcen.2000.7507 }}$

Okafor OL, Okoro VMO, Mbajiorgu CA, Okoli IC, Ogbuewu IP and Ogundu UE, 2019. Influence of chicken growth hormone (cGH) SNP genotypes on morphometric and growth traits of three chicken breeds in Nigeria. Indian Journal of Animal Science 53: 1559-1565. https://doi.org/ 10.18805/ijar.B-1077

Omori R and Wu J, 2017. Tajima's D and site-specific nucleotide frequency in a population during an infectious disease outbreak. Siam Journal on Applied Mathematics 77: 21562171. https://doi.org/10.1137/17M114946

Osman MMM, Hemeda S, Hassanin, AAI and Walaai A, 2017. Polymorphism of prolactin gene and its association with egg production trait in four commercial chicken lines. Journal of the Hellenic Veterinary Medical Society 68: 391-404. https://doi.10.12681/jvms.15502

Panhuis TM and Swanson WJ, 2006. Molecular evolution and population genetic analysis of candidate female reproductive genes drosophila. Genetics 173: 2039-2047. https://doi.org/ 10.1534/genetics.105.053611

Rashidi H, Rahimi-Mianji G, Farhadi A and Gholizadeh M, 2012. Association of prolactin and prolactin receptor gene polymorphisms with economic traits in breeder hens of indigenous chickens of Mazandaran province. Iran Journal of Biotechnology 10: 129-135.

Raymond F, 2008. Genepop'007: A complete reimplementation of the Genepop software for Windows and Linux. Molecular Ecology Resource 8: 103-106. https://doi.org/10.1111/ j.1471-8286.2007.0193.x.

Reshma RS and Das DN, 2021. Molecular markers and its application in animal breeding. In: Advances in Animal Genomics. Academic Press. Mondal S and Singh RL (ed), pp: 123-140. https://doi.org/10.1016/B978-0-12-820595-2. $\underline{00009-6}$

Sambrook J and Russell DW, 2001. Molecular Cloning: A Laboratory Manual, $3^{\text {rd }}$ Ed. Cold Spring Harbor Laboratory Press, Cold Spring Harbor, New York, USA.

Shaw M, Nielson H and Rose M, 2019. Poultry sector study. Department for international development. PO 11144-142. Final draft. Available from: https://www.bdsknowledge.org/ dvn/bds/docs/960/DFID\%20Poultry\%20Sector\%20Study\% 20180419.pdf

Sonmez Z and Ozdemir M, 2017. Prolactine-Rsal gene polymorphism in Est Anatolian red cattle in Turkey. South
African Journal of Animal Science 47: 124-129. http://dx.doi.org/10.4314/sajas.v47i2.3

Spötter A, Gupta P, Mayer M, Reinsch N and Bienefeld K, 2016. Genome-wide association study of a Varroa-specific defense behavior in honeybees (Apis mellifera). Journal of Heredity 107: 220-227. https://doi.org/10.1093/jhered/esw005

Tajima F, 1989. Statistical method for testing the neutral mutation hypothesis by DNA polymorphism. Genetics 123: 585-595.

Tajima F, 1993. Measurements of DNA polymorphism. In: Mechanisms of molecular evolution. Takahata $\mathrm{N}$ and Clark AG (ed), Sinaeur Associates, Sunderland, MA pp: 37-59.

Takahata N, 1990. A simple genealogical structure of strongly balanced allelic lines and trans-species polymorphism. Proc Natl Acad Sci USA 87: 2419-2423. https://doi.org/ 10.1073/pnas.87.7.2419

Tamura K, Stecher G, Peterson D, Filipski A and Kumar S, 2013. MEGA6: Molecular Evolutionary Genetics Analysis version 6.0. Molecular Biology and Evolution 30: 2725-2729. https://doi.org/10.1093/molbev/mst197

Vekemans X and Slatkin M, 1994. Gene and allelic genealogies at a gametophytic self-incompatibility locus. Genetics 137 : 1157-1165.

Visscher PM, Wray NR, Zhang Q, Sklar P, McCarthy MI, Brown MA and Yang J, 2017. 10 Years of GWAS discovery: Biology, function, and translation. The American Journal of Human Genetics, 101: 5-22. https://doi.org/10.1016/j.ajhg. 2017.06.005

Wang C, Liang Z, Yu W, Feng Y, Peng X, Gong Y and Li S, 2011. Polymorphism of the prolactin gene and its association with egg production traits in native Chinese ducks. South African Journal of Animal Science 41: 63-69.

Watahiki M, Tanaka M, Masudam N, Sugisakim K, Yamamatom M, Yamakawa M, Nagai J and Nakashima K, 1989. Primary structure of chicken pituitary prolactin deduced from the cDNA sequence. Conserved and specific amino acid residues in the domains of the prolactin. The Journal of Biology Chemistry 264: 5535-5539.

Yournalis A, Kasmsa Z and Putra DE, 2019. Polymorphism of prolactin genes and its association with body weight in Banyang ducks, local ducks from West Sumatera, Indonesia. International Conference on Animal Production for Food Sustainability. IOP Conference Series: Earth and Environmental Science. 287: 012009. https://doi.org/ $\underline{10.1088 / 17755-1-315 / 287 / 1 / 012009}$ 